\title{
DZNep and UNC0642 enhance in vitro developmental competence of cloned pig embryos
}

\author{
Chengfa Zhao ${ }^{1}$, Junsong Shi², Rong Zhou², Xiaoyan He ${ }^{1,2}$, Huaqiang Yang ${ }^{1,2}$ and Zhenfang Wu ${ }^{1,2}$ \\ ${ }^{1}$ National Engineering Research Center for Breeding Swine Industry, College of Animal Science, South China \\ Agricultural University, Guangzhou, China and ${ }^{2}$ Wens Foodstuff Group Co., Ltd., Yunfu, China
}

Correspondence should be addressed to H Yang or Z Wu; Email: yangh@scau.edu.cn orwzf@scau.edu.cn

\begin{abstract}
Somatic cell nuclear transfer in mammalian cloning suffers from a faulty epigenetic reprogramming, which is believed to cause developmental failures in cloned embryos. Regulating the epigenetic-modifying enzymes can rescue the chromatin of cloned embryos from aberrant epigenetic status, thereby potentially promoting cloning efficiency. In this study, we investigated the effect of two histone methyltransferase inhibitors, namely, DZNep and UNC0642, on the in vitro developmental competence of cloned pig embryos. We found that (1) treatment with $10 \mathrm{nM}$ DZNep or $5 \mathrm{nM}$ UNC0642 for $24 \mathrm{~h}$ after activation had the best promoting effect on the development of cloned embryos (blastocyst rate $10.32 \%$ vs $18.08 \%$ for DZNep, and $10.44 \%$ vs $18.14 \%$ for UNC0642); (2) $10 \mathrm{nM}$ DZNep and $5 \mathrm{nM}$ UNC0642 significantly decreased the levels of H3K27me3 and H3K9me2, respectively, at the 2-cell, 4-cell and blastocyst stages; (3) the apoptosis level was lower in the treatment groups than in untreated control; and (4) the transcriptional expression of epigenetic genes (EZH2, GLP, G9a, Setdb1, Setdb2, Suv39h1 and Suv39h2) was decreased and pluripotency genes (Nanog, Pou5f1, Sox2 and Bmp4) was increased in treatment groups compared with control. These results indicated that treatment with DZNep and UNC0642 improves the epigenetic reprogramming of cloned embryos, which could render beneficial effect on the embryo quality and aberrant gene expression, and finally improve the developmental competence of cloned pig embryos.

Reproduction (2019) 157 359-369
\end{abstract}

\section{Introduction}

Animal cloning via somatic cell nuclear transfer (SCNT) is an assisted reproductive technology that can reprogram terminally differentiated somatic cells to the embryonic state and further develop them into individual animals (Wilmut et al. 1997, Wakayama et al. 1998, Onishi et al. 2000, Polejaeva et al. 2000, Hochedlinger \& Jaenisch 2002, Campbell et al. 2007). Cloning technology can be used for multiplying elite animal individuals faster and simpler than traditional breeding programs (Galli et al. 2012). Additionally, it can be applied to creation of genetically modified animals, conservation of endangered species and therapeutic cloning for regenerative medicine (Prather et al. 2003, Galli et al. 2012, Tachibana et al. 2013, Chung et al. 2014). Since the first cloned mammal, 'Dolly' the sheep, was born in 1997 (Wilmut et al. 1997), more than 20 cloned mammalian species, including nonhuman primate, have been successfully generated (Thuan et al. 2010, Liu et al. 2018, Matoba \& Zhang 2018). Moreover, large-scale commercial cloning has been applied in some livestock, such as pigs and cattle. However, the cloning efficiency remains low in essentially all species. The live birth rate obtained from SCNT embryos is only
1\%-5\% (Wilmut et al. 2002, Campbell et al. 2007), which significantly limits practical application of SCNT in a cost-effective way.

Reasons behind the inefficiency of cloning have not been fully understood, but incomplete nuclear reprogramming of donor cell by the oocyte is believed to be the contributor to reduce cloning efficiency (Niemann \& Wrenzycki 2000, Dean et al. 2001, Kang et al. 2001, Rideout et al. 2001, Santos et al. 2003). The nuclear reprogramming process mainly involves various epigenetic modifications, including DNA methylation and covalent modifications of histones, which are crucial in altering the chromatin structure, DNA accessibility and gene transcription, and consequently into operating ongoing biological processes (Allis \& Jenuwein 2016). Studies on epigenetic patterns of embryos have shown abnormal DNA methylation/histone modification dynamics and distribution patterns in SCNT embryos compared with fertilized (in vitro or in vivo conditions) counterparts across several species (Dean et al. 2001, Kang et al. 2001, Beaujean et al. 2004, Cao et al. 2015, Huang et al. 2016, Zhang et al. 2016). These abnormal epigenetic marks (usually repressive marks) contribute to heterochromatin formation and aberrant gene expression, and therefore, adversely impact the 
developmental efficiency of cloned embryos. Among the epigenetic modifications, histone methylation is of particular interest given a diverse set of methylationrelevant biological processes exist, because methylation status at different histone residues can exhibit transcriptional activation or repression effects (Nottke et al. 2009, Greer \& Shi 2012, Hyun et al. 2017). Lysine residue 9 (H3K9) and lysine residue 27 (H3K27) of histone $\mathrm{H} 3$ were identified as transcription-repressive marks. Their methylation levels were associated with transcriptional repression and negative regulation of somatic reprogramming (Chen et al. 2013, Mozzetta et al. 2014, Cao et al. 2015, Pan et al. 2018). Aberrant $\mathrm{H} 3 \mathrm{~K} 9$ and H3K27 methylation levels were observed in pig SCNT embryos (Cao et al. 2015, Huang et al. 2016, Xie et al. 2016). The histone lysine demethylases which control the methylation status of lysine residues in the histone H3 (H3K4, H3K9, H3K27) were also observed to be improperly expressed during cell reprogramming in porcine and bovine SCNT embryos compared with that of in vitro fertilized (IVF) embryos, proposing an improper establishment of the histone methylation in SCNT embryos (Glanzner et al. 2018). Therefore, the histone methylation marks required modulation to sustain normal development in SCNT embryos. As a rescue strategy, overexpression of histone demethylase KDM4A and KDM4D, which specifically target H3K9 methylation (Matoba et al. 2014, Chung et al. 2015), or inhibition of histone methyltransferase (HMT) G9a, which catalyzes H3K9 methylation (Huang et al. 2016), could significantly promote the cloning efficiency in mice and pigs, as well as the human SCNT blastocyst formation and SCNT-derived embryonic stem cell derivation.

Several small-molecule compounds that target epigenetic modifiers have been applied to adjust epigenetic remodeling in order to improve cloning efficiency during SCNT in many species. Three categories of compounds commonly used for this purpose are DNA methyltransferase inhibitors (such as 5-aza-2'deoxyctidine) (Enright et al. 2003), histone deacetylase inhibitors (such as trichostatin A and scriptaid) (Li et al. 2008, Zhao et al. 2009) and HMT inhibitors (such as BIX-01294 and GSK126) (Huang et al. 2016, Xie et al. 2016). Three-Deazaneplanocin A (DZNep) (Gannon et al. 2013, Ostrup et al. 2014) and UNC0642 (Liu et al. 2013, Kim et al. 2017) are HMT inhibitors displaying excellent separation of functional potency and cell toxicity, thus suitable for cell-based and animal studies. DZNep and UNC0642 can cause selective reductions of H3K27me3 and H3K9me2, respectively. Their effects on the development of SCNT embryos have not been reported. We here investigated the effect of treatment with DZNep and UNC0642 on the developmental rate, epigenetic status, quality and gene expression of cloned pig embryos.

\section{Materials and methods}

All chemicals were purchased from Sigma and the media were obtained from Thermo Fisher unless otherwise stated.

\section{Fibroblasts isolation}

The nuclear donor cells were adult pig fibroblasts isolated from ear skin. A small piece of skin from pig ear was cut out, and surface sterilized by soaking in $75 \%$ ethanol for $5 \mathrm{~min}$. The tissue was subsequently shaved, and diced into millimeter square pieces on a Petri dish. A dissociation buffer including $0.64 \mathrm{~g} / \mathrm{L}$ collagenase IV, $15 \%$ fetal bovine serum, and $2 \%$ antibiotic-antimycotic solution in DMEM was used to digest the tissue for $3 \mathrm{~h}$ at $38.5^{\circ} \mathrm{C}$ in a $5 \% \mathrm{CO}_{2}$ incubator. Afterward, the dissociated tissues were collected and pelleted by centrifuge, reseeded on a Petri dish in a DMEM containing 15\% FBS and $2 \%$ antibiotic-antimycotic solution, and maintained at $38.5^{\circ} \mathrm{C}$ in a $5 \% \mathrm{CO}_{2}$ incubator with humidity. The fibroblasts began to creep out of the tissues the next day and further spread to reach confluence.

\section{Oocyte collection and in vitro maturation}

The pig ovaries were collected from a local slaughterhouse, stored in physiological saline with antibiotics, and transported to the laboratory at $37^{\circ} \mathrm{C}$. Follicular fluid was aspirated from the follicles between 3 and $8 \mathrm{~mm}$ in diameter using a syringe. Cumulus oocyte complexes (COCs) in follicular fluid were allowed to settle at $38.5^{\circ} \mathrm{C}$, and then washed three times with HEPES-buffered Tyrode's lactate (HEPES-TL). Only COCs with a uniform ooplasm and at least three layers of intact cumulus cells were subjected to in vitro maturation (IVM). COCs were distributed in groups of 50-100 in four-well culture plates containing $500 \mu \mathrm{L}$ IVM medium covered with $300 \mu \mathrm{L}$ sterile mineral oil per well, and cultured for $42-44 \mathrm{~h}$ under an atmosphere of $5 \% \mathrm{CO}_{2}$ in humidified air at $38.5^{\circ} \mathrm{C}$. Matured COCs were vortexed in $0.1 \%(\mathrm{w} / \mathrm{v})$ hyaluronidase in HEPES-TL for $3 \mathrm{~min}$ to strip the cumulus cells. The matured oocytes with an extruded first polar body (Metaphase II, MII) with homogenous cytoplasm were used for SCNT.

\section{Somatic cell nuclear transfer}

SCNT was performed as previously described with some minor modifications (Lai \& Prather 2003). Briefly, we enucleated the MII oocytes via aspiration of the polar body, MII chromosome and a small amount of adjacent cytoplasm using a beveled glass pipette in porcine zygote medium-3 (PZM3) containing $7.5 \mu \mathrm{g} /$ $\mathrm{mL}$ cytochalasin $\mathrm{B}$ at $38.5^{\circ} \mathrm{C}$. Afterward, we injected a single intact donor cell into the perivitelline space of an enucleated oocyte with the same pipette. The reconstructed nuclear donor cell-oocyte cytoplasm complexes were simultaneously fused and activated by using two direct pulses of $1.2 \mathrm{kv} / \mathrm{cm}$ for $30 \mu \mathrm{s}$ using a BTX Electro-Cell Manipulator. The fusion rate was evaluated by using stereomicroscopic examination. The activated embryos were transferred to four-well culture plates 
containing $500 \mu \mathrm{L}$ PZM3 and $300 \mu \mathrm{L}$ mineral oil per well, and maintained in a humidified $38.5^{\circ} \mathrm{C}, 5 \% \mathrm{CO}_{2}$ incubator for 48 and $156 \mathrm{~h}$ to examine the cleavage and blastocyst rates, respectively. For counting cell number of embryos, blastocysts were washed twice in $100 \mu \mathrm{L}$ drop of PBS containing $0.1 \mathrm{mg} /$ $\mathrm{mL}$ polyvinyl alcohol (PBS-PVA), and then transferred to a $50 \mu \mathrm{L}$ microdrop of Hoechst 33342 working solution $(1 \mu \mathrm{g} / \mathrm{mL}$ Hoechst 33342 in PBS-PVA) for nuclear staining for $10 \mathrm{~min}$. The stained blastocysts were washed in PBS-PVA, mounted to slides and analyzed under the fluorescence microscope with a UV filter.

\section{In vivo-derived embryos}

A multiparous sow (Duroc) was artificially inseminated after the estrus was examined. The day of insemination was considered as day 1 . The sow was sacrificed on day 7 and the uterus was excised and transported to the laboratory in physiological saline with antibiotics at $37^{\circ} \mathrm{C}$. The embryos were flushed out of the uterus, and the embryos at blastocyst stage were collected and transferred into PBS-PVA. Afterward, the embryos were rinsed thrice in PBS and subjected to RNA extraction.

\section{DZNep and UNC0642 treatment}

DZNep (SML0305, Sigma) and UNC0642 (SML1037, Sigma) were dissolved in DMSO and stored at $-20^{\circ} \mathrm{C}$. PZM3 medium was used to dilute DZNep and UNC0642 stock solution to obtain the desired working solutions $(0,1,10,50$ or $100 \mathrm{nM}$ for DZNep, and 0, 1, 5, 10, 50 or 100 nM for UNC0642). For $0 \mathrm{nM}$ treatment groups, DMSO was added into PZM3 as the culture medium. After activation, the reconstructed embryos were cultured in PZM3 containing DZNep or UNC0642 for the indicated times $(0,24,48$ or $72 \mathrm{~h})$. Afterward, the treated embryos were washed thrice and cultured in fresh PZM3 without treatment until reaching the blastocyst stage.

\section{Immunofluorescence}

Ten SCNT embryos at each of 2-cell, 4-cell and blastocyst stages were collected from all compound-treated and control groups, washed in PBS-PVA, fixed in $4 \%$ paraformaldehyde (PFA) in PBS for $15 \mathrm{~min}$ and permeabilized using $0.1 \%$ Triton $\mathrm{X}-100$ in PBS for $15 \mathrm{~min}$. The embryos were then blocked in blocking solution consisting of $5 \%$ BSA (w/v) in PBS for $1 \mathrm{~h}$ at room temperature and stained with mouse monoclonal primary antibodies against H3K27me3 (1:200; ab6002, Abcam), H3K9me2 (1:200; ab1220, Abcam) and H3K9me3 (1:200; NBP1-30141, Novus) overnight at $4^{\circ} \mathrm{C}$. After extensive washing with PBS-PVA, the embryos were incubated with the secondary antibody, Alexa Fluor 488 conjugated goat antimouse IgG (A11001, Thermo Fisher), for $1 \mathrm{~h}$ in the darkness at room temperature. The nuclei of embryos were stained with $1 \mu \mathrm{g} / \mathrm{mL}$ Hoechst 33342. The images were captured using an inverted fluorescence microscope (Olympus) and the fluorescence intensity was quantified using ImageJ (NIH). For fluorescence intensity quantification, the nucleus region positive for Hoechst 33342 was manually outlined as the measuring area, in which the green fluorescence intensity was measured after the background subtraction of the cytoplasmic area from the whole image. The values were expressed as the mean fluorescence intensity per nucleus by averaging all nuclei signals of at least three embryos (2-cell, 4-cell embryos and blastocysts).

\section{TUNEL assay}

TUNEL (TdT-mediated dUTP-digoxigenin nick end labeling) assay (KeyGen Biotech) was performed to detect apoptotic DNA fragmentation according to the manufacturer's protocol. Reconstructed embryos were split into three groups and treated with $10 \mathrm{nM}$ DZNep, $5 \mathrm{nM}$ UNC0642 and DMSO after activation, respectively. TUNEL assay was performed with ten blastocysts for each group. Blastocysts were fixed in 4\% PFA and permeabilized with $0.1 \%$ Triton X-100 in $0.1 \%$ sodium citrate. After washing in PBS, blastocysts were incubated in TUNEL reaction mixture (equilibration buffer + TRITC-dUTP +TdT enzyme) for $1 \mathrm{~h}$ in the darkness at $37^{\circ} \mathrm{C}$. Furthermore, the blastocysts were counterstained with $300 \mathrm{nM}$ 4,6-diamidino2-phenylindole (DAPI) for $5 \mathrm{~min}$ to identify the nuclei.

\section{Quantitative PCR}

Total RNA was extracted using TRIzol Reagent (Thermo Fisher) from 20 to 30 blastocysts for each treatment group. Afterward, reverse transcription was performed to synthesize cDNA. The quantitative PCR was conducted with Takara SYBR Premix Ex Taq by using cDNA as template and specific primers for each gene in a QuantStudio 7 Flex Real-Time PCR System (Applied Biosystems). The amplification of each gene was performed in four replicates and the Ct values were obtained for each reaction. The transcript abundance of each gene was calculated relative to those of the internal control gene $\beta$-actin using the $2^{-\Delta \Delta C t}$ method.

\section{Statistical analysis}

All experiments were repeated at least thrice. Statistical analysis was performed with GraphPad Prism (GraphPad Software) by using one-way analysis of variance (ANOVA). All data are expressed as mean \pm S.E.M. (standard error of mean). The level of significance is fixed at $0.05\left(^{*}\right)$ or $0.01\left(^{* *}\right)$.

\section{Results}

\section{Effects of DZNep and UNC0642 treatments on the in vitro development of reconstructed pig embryos}

To investigate the effects of DZNep and UNC0642 treatment on SCNT embryo development, we treated pig SCNT embryos with either DZNep (0, 1, 10, 50 and $100 \mathrm{nM})$ or UNC0642 (0, 1, 5, 10, 50 and $100 \mathrm{nM})$ for $24 \mathrm{~h}$. Afterward, the compounds were washed out and the embryos were cultured in fresh PZM3 until day 7. Treatment with DZNep at 1, 10 and $50 \mathrm{nM}$ (Table 1), as well as UNC0642 at 1 and $5 \mathrm{nM}$ (Table 2), showed increasing trends in the blastocyst rate and total cell 
Table 1 Effect of $24 \mathrm{~h}$ treatment with DZNep at different concentrations on the developmental competence of pig cloned embryos.

\begin{tabular}{lcccccc}
\hline $\begin{array}{l}\text { Concentration of } \\
\text { DZNep }(\mathrm{nM})(\text { replicates) }\end{array}$ & Embryos $(n)$ & $\begin{array}{c}\text { Cleaved } \\
\text { embryos }(n)\end{array}$ & Cleavage rate $(\%)$ & Blastocysts $(n)$ & Blastocyst rate $(\%)$ & Total cell number \\
\hline $0(4)$ & 148 & 104 & $70.05 \pm 1.21$ & 15 & $10.32 \pm 1.14^{\mathrm{b}}$ & $45.40 \pm 2.66^{\mathrm{b}}$ \\
$1(4)$ & 154 & 111 & $72.33 \pm 3.01$ & 22 & $14.35 \pm 0.62^{\mathrm{b}}$ & $50.38 \pm 1.00^{\mathrm{a}, \mathrm{b}}$ \\
$10(7)$ & 268 & 201 & $74.96 \pm 1.36$ & 48 & $18.08 \pm 0.87^{\mathrm{a}}$ & $54.70 \pm 1.16^{\mathrm{a}}$ \\
$50(4)$ & 149 & 105 & $71.01 \pm 3.59$ & 18 & $12.19 \pm 0.87^{\mathrm{b}}$ & $48.38 \pm 2.33^{\mathrm{b}}$ \\
$100(4)$ & 167 & 117 & $70.20 \pm 2.53$ & 14 & $8.37 \pm 0.53^{\mathrm{c}}$ & $44.13 \pm 1.68^{\mathrm{b}}$ \\
\hline
\end{tabular}

$a, b, c$ Values with different superscripts within the same column differ significantly $(P<0.05)$.

number of blastocysts compared with 0 nM DZNep and $0 \mathrm{nM}$ UNC0642 treatment, respectively; moreover, $10 \mathrm{nM}$ DZNep and $5 \mathrm{nM} \mathrm{UNC0642}$ treatments yielded the highest blastocyst rate $(18.08 \%$ vs $10.32 \%$ for DZNep, and $18.14 \%$ vs $10.44 \%$ for UNC0642, $P<0.05$ ) and total cell number (54.70 vs 45.40 for DZNep, and 57.46 vs 49.71 for UNC0642, $P<0.05)$ among groups (Fig. 1 and Tables 1,2). The cleavage rate showed a concomitant increase with the increasing blastocyst rate, but the difference was not significant. We next treated the pig SCNT embryos with $10 \mathrm{nM}$ DZNep or $5 \mathrm{nM}$ UNC0642 at different exposure durations (0, 24, 48 and $72 \mathrm{~h}$ ). Results showed that $24 \mathrm{~h}$ treatment with either compound yielded the highest blastocyst rate ( $16.67 \%$ vs $11.11 \%$ for DZNep, and $18.57 \%$ vs $9.52 \%$ for UNC0642, $P<0.05)$ and total cell number $(52.67$ vs 42.92 for DZNep, and 50.07 vs 43.27 for UNC0642, $P<0.05)$ among groups, whereas results from the 48 and $72 \mathrm{~h}$ treatments were not significantly different from the $0 \mathrm{~h}$ treatment group (Tables 3 and 4). Afterward, we treated the cloned embryos with a mixture of $10 \mathrm{nM}$ DZNep and $5 \mathrm{nM}$ UNC0642 for 0, 24 and $48 \mathrm{~h}$. Following the treatment, the three groups showed no significant differences in the cleavage and blastocyst rates and total cell number. However, compared with $0 \mathrm{~h}$ treatment, the blastocyst rate and total cell number after $24 \mathrm{~h}$ treatment with the mixed compounds showed a tendency to increase from $11.04 \%$ to $13.70 \%$, and 47.00 to 52.22 , respectively (Table 5 ).

\section{Epigenetic effects of DZNep and UNC0642 on reconstructed pig embryos}

The epigenetic status of the compound-treated SCNT embryos was evaluated by using immunofluorescence staining and quantitative analysis. The H3K27me3 was significantly reduced following DZNep treatment compared with that in the control (Fig. 2A). Through quantifying the fluorescence intensity, the H3K27me3 marks decreased by approximately $45 \%(P<0.01), 37 \%$ $(P<0.01)$ and $7 \%(P<0.05)$ at the 2 -cell, 4 -cell and blastocyst stages, respectively, compared with control (Fig. 2B). The UNC0642 treatment resulted in decreased H3K9me2 (Fig. 3A and B), but not trimethylated H3K9me3 (Fig. 4A and B) at the 2-cell, 4-cell and blastocyst stages; this was consistent with previous reports, wherein UNC0642 specifically inhibited G9a, which catalyzes dimethylated states of H3K9 (Shinkai \& Tachibana 2011, Liu et al. 2013). Fluorescence intensity assay showed approximately $13 \% \quad(P<0.05), \quad 47 \%$ $(P<0.01)$ and $29 \%(P<0.05)$ decreases in H3K9me2 marks for the embryos at 2-cell, 4-cell and blastocyst stages, respectively, compared with control (Fig. 3B).

\section{Effects of DZNep and UNC0642 on the apoptosis status of reconstructed pig embryos}

We further investigated the apoptosis level of cloned embryos exposed to $10 \mathrm{nM}$ DZNep and $5 \mathrm{nM} \mathrm{UNC0642.}$ TUNEL assay of the cloned embryos showed lower TUNEL positivity after DZNep and UNC0642 treatments compared with the DMSO-treated control (Fig. 5A). Moreover, we stained the blastocyst nuclei with DAPI and found markedly higher nuclear fragmentation level in the control cloned embryos than those treated with DZNep or UNC0642 (Fig. 5A). The fragmented nuclei were mostly merged with TUNEL positivity, thereby indicating the occurrence of apoptosis in the stained cells. TUNEL result showed that DZNep and UNC0642 treatment could decrease the apoptotic index of the

Table 2 Effect of $24 \mathrm{~h}$ treatment with UNC0642 at different concentrations on the developmental competence of pig cloned embryos.

\begin{tabular}{lcccccc}
\hline $\begin{array}{l}\text { Concentration of } \\
\text { UNC0642 }(\mathrm{nM}) \\
\text { (replicates) }\end{array}$ & Embryos $(n)$ & $\begin{array}{c}\text { Cleaved } \\
\text { embryos }(n)\end{array}$ & Cleavage rate $(\%)$ & Blastocysts $(n)$ & Blastocyst rate $(\%)$ & Total cell number \\
\hline $0(4)$ & 163 & 113 & $69.31 \pm 0.83^{\mathrm{a}}$ & 17 & $10.44 \pm 1.21^{\mathrm{c}}$ & $49.71 \pm 1.73^{\mathrm{b}}$ \\
$1(3)$ & 141 & 101 & $71.16 \pm 1.96^{\mathrm{a}}$ & 20 & $14.13 \pm 0.85^{\mathrm{b}}$ & $50.60 \pm 2.12^{\mathrm{a}, \mathrm{b}}$ \\
$5(5)$ & 203 & 146 & $71.91 \pm 1.79^{\mathrm{a}}$ & 37 & $18.14 \pm 1.32^{\mathrm{a}}$ & $57.46 \pm 2.24^{\mathrm{a}}$ \\
$10(5)$ & 208 & 144 & $69.37 \pm 1.66^{\mathrm{a}}$ & 22 & $10.62 \pm 0.44^{\mathrm{c}}$ & $50.56 \pm 2.21^{\mathrm{a}, \mathrm{b}}$ \\
$50(5)$ & 237 & 163 & $68.67 \pm 1.57^{\mathrm{a}}$ & 20 & $8.73 \pm 0.62^{\mathrm{c}}$ & $47.00 \pm 2.83^{\mathrm{b}, \mathrm{c}}$ \\
$100(5)$ & 243 & 148 & $60.68 \pm 2.58^{\mathrm{b}}$ & 12 & $4.69 \pm 0.99^{\mathrm{d}}$ & $40.75 \pm 3.20^{\mathrm{c}}$ \\
\hline
\end{tabular}

$a, b, c, d$ Values with different superscripts within the same column differ significantly $(P<0.05)$. 

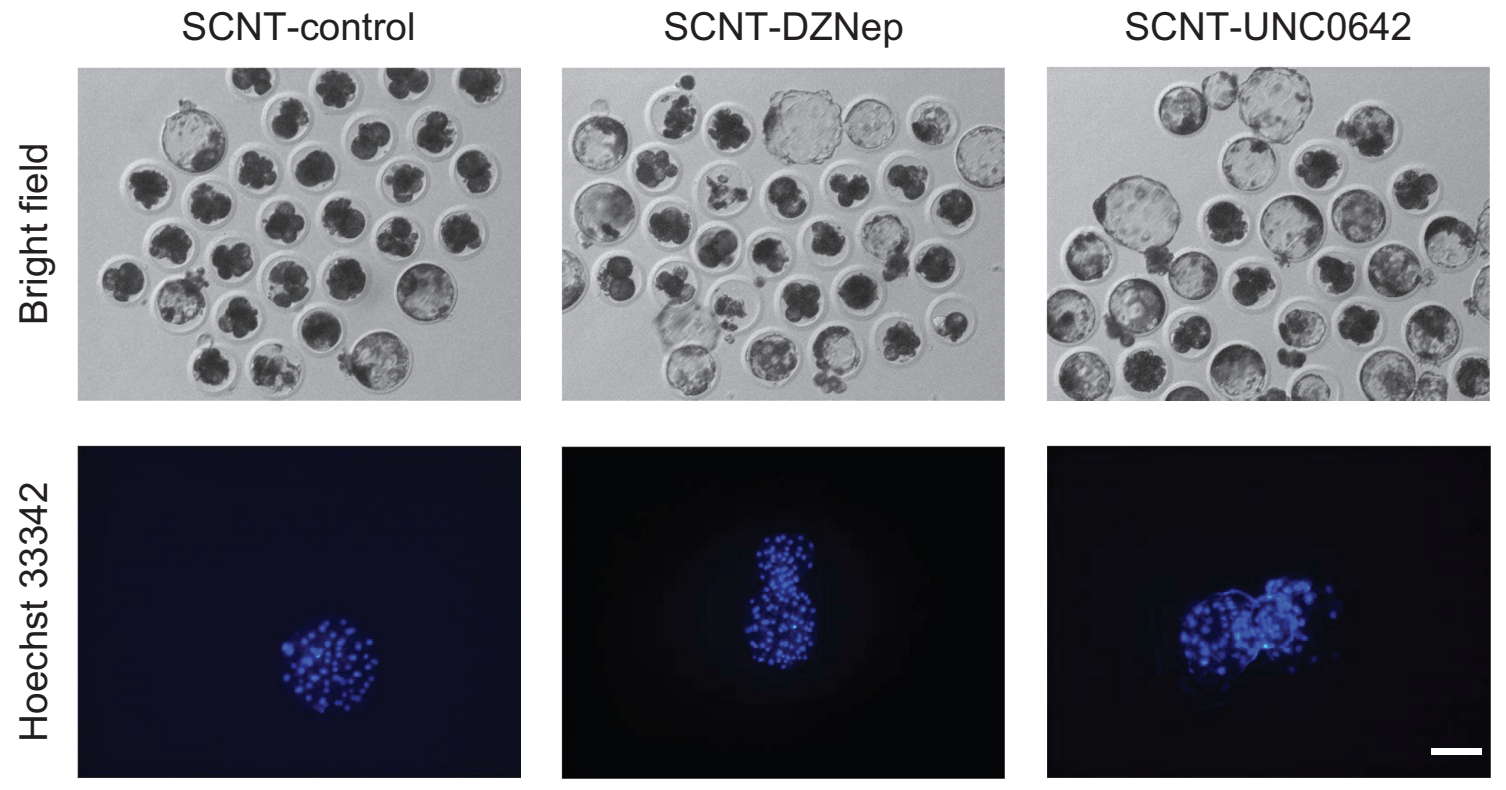

Figure 1 DZNep and UNC0642 treatments enhance the developmental efficiency of cloned embryos. The SCNT reconstructed embryos were treated with $10 \mathrm{nM}$ DZNep or $5 \mathrm{nM} \mathrm{UNC0642}$ for $24 \mathrm{~h}$ after activation, and DMSO treatment was used as control. The medium was replaced with fresh PZM3 without compound addition until day 7. Upper panel shows the representative images of cloned blastocysts at $156 \mathrm{~h}$ after activation from different groups under the bright field. Lower panel shows the representative images of cloned blastocysts stained with Hoechst 33342 for total cell number counting. Significantly increased blastocyst rate and total cell number can be observed in the DZNep and UNC0642 treatment groups compared with control. Scale bars $=100 \mu \mathrm{m}$.

cloned pig embryos. This result was further confirmed by quantifying the expression level of Bax, which functions as an apoptosis activator. The blastocysts in the DZNep and UNC0642 treatment groups demonstrated a significant decrease in Bax level compared with DMSOtreated control group (Fig. 5B). The Bax level of the compound-treated embryos remained higher than that of in vivo-derived (IVV) embryos; however, it showed a tendency toward the low apoptotic index, thereby implying the beneficial effects of DZNep and UNC0642 treatments on the quality of cloned pig embryos.

\section{Effects of DZNep and UNC0642 on chromatin- modifying enzymes and pluripotency factors}

To investigate the underlying mechanism of the improved developmental competence of cloned embryos exposed to DZNep and UNC0642, multiple HMT genes (EZH2, GLP, G9a, Setdb1, Setdb2, Suv39h1 and Suv39h2) and pluripotency genes (Nanog, Pou5f1, Sox 2 and Bmp4) were determined by using quantitative
PCR at blastocyst stage. Results showed that DZNep treatment significantly decreased the EZH2 mRNA level, and UNC0642 significantly decreased G9a and GLP mRNA levels (Fig. 6A). Moreover, we observed decreases in other HMTs in mRNA levels, thereby likely reflecting that DZNep and UNC0642 can unselectively inhibit the expression of multiple chromatin-modifying enzymes. Pluripotency-related genes, namely Nanog, Pou5f1, Sox2 and Bmp4, exhibited a great increase in compound-treated blastocysts, indicating enhanced pluripotency in SCNT embryos exposed to DZNep and UNC0642 (Fig. 6B).

\section{Discussion}

The SCNT process involves a global epigenetic remodeling. However, epigenetic reprogramming of DNA and histone is inefficient in most cloned embryos, thereby affecting cloning efficiency (Long et al. 2014, Matoba \& Zhang 2018). Histone methylation plays a crucial role in the maintenance of stem cell pluripotency

Table 3 Effect of $10 \mathrm{nM}$ DZNep treatment for different exposure durations on the developmental competence of pig cloned embryos.

\begin{tabular}{lcccccc}
\hline $\begin{array}{l}\text { Treatment duration } \\
\text { (h) (replicates) }\end{array}$ & Embryos $(n)$ & $\begin{array}{c}\text { Cleaved } \\
\text { embryos }(n)\end{array}$ & Cleavage rate $(\%)$ & Blastocysts $(n)$ & Blastocyst rate $(\%)$ & Total cell number \\
\hline $0(3)$ & 99 & 77 & $77.78 \pm 2.67$ & 11 & $11.11 \pm 1.01^{\mathrm{b}}$ & $42.92 \pm 1.73^{\mathrm{b}}$ \\
$24(3)$ & 102 & 81 & $79.41 \pm 2.40$ & 17 & $16.67 \pm 0.98^{\mathrm{a}}$ & $52.67 \pm 1.27^{\mathrm{a}}$ \\
$48(3)$ & 99 & 66 & $73.74 \pm 2.67$ & 10 & $10.10 \pm 1.01^{\mathrm{b}}$ & $43.83 \pm 3.28^{\mathrm{b}}$ \\
$72(3)$ & 103 & 74 & $71.86 \pm 1.71$ & 9 & $9.69 \pm 0.88^{\mathrm{b}}$ & $44.57 \pm 2.47^{\mathrm{b}}$ \\
\hline
\end{tabular}

a,b Values with different superscripts within the same column differ significantly $(P<0.05)$. 


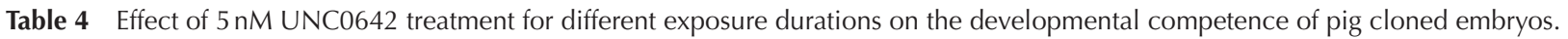

\begin{tabular}{lcccccc}
\hline $\begin{array}{l}\text { Treatment duration } \\
\text { (h) (replicates) }\end{array}$ & Embryos $(n)$ & $\begin{array}{c}\text { Cleaved } \\
\text { embryos }(n)\end{array}$ & Cleavage rate $(\%)$ & Blastocysts $(n)$ & Blastocyst rate $(\%)$ & Total cell number \\
\hline $0(3)$ & 105 & 80 & $76.19 \pm 3.43$ & 10 & $9.52 \pm 0.95^{\mathrm{b}}$ & $43.27 \pm 1.80^{\mathrm{b}}$ \\
$24(3)$ & 119 & 94 & $79.05 \pm 2.79$ & 22 & $18.57 \pm 0.99^{\mathrm{a}}$ & $50.07 \pm 1.54^{\mathrm{a}}$ \\
$48(3)$ & 126 & 92 & $73.02 \pm 2.86$ & 15 & $11.90 \pm 1.37^{\mathrm{b}}$ & $46.38 \pm 2.93^{\mathrm{b}}$ \\
$72(3)$ & 119 & 91 & $72.86 \pm 2.25$ & 12 & $10.08 \pm 0.99^{\mathrm{b}}$ & $44.43 \pm 2.91^{\mathrm{b}}$ \\
\hline
\end{tabular}

a,b Values with different superscripts within the same column differ significantly $(P<0.05)$.

and early embryo development (Greer \& Shi 2012, Hyun et al. 2017). Studies on mouse embryos have shown that levels of arginine methylation of $\mathrm{H} 3$ in four-cell blastomeres is associated with the development of inner cell mass (Torres-Padilla et al. 2007). H3K9 methylation has been found to be the primary epigenetic determinant during somatic cell reprogramming into induced pluripotent stem cells (iPSCs), and removal of $\mathrm{H} 3 \mathrm{~K} 9$ methylation leads to fully reprogrammed iPSCs (Chen et al. 2013). Additionally, H3K79me2 acts as a barrier to repress reprogramming, and inhibition of H3K79specific methyltransferase DOT1L by shRNA-mediated knockdown or small-molecule inhibitor could facilitate iPSC generation (Onder et al. 2012). In pig cloning, aberrant histone methylation marks have been observed in SCNT-derived pig embryos (Cao et al. 2015, Huang et al. 2016, Xie et al. 2016). Selective HMT inhibitors could improve cloning efficiency by preventing the nuclear chromatin of cloned embryos from reaching the aberrant methylation status (Huang et al. 2016, Xie et al. 2016). In contrast, treatment with small-molecule inhibitor of histone demethylases decreased the cloned embryonic development (Xie et al. 2016).

Application of chromatin-modifying small molecules is a simple and effective method to correct aberrant epigenetic reprogramming. Multiple HMT inhibitors have been identified but few have been investigated for their effects on SCNT reprogramming. DZNep can reduce histone methylation level by disrupting the activity of HMT EZH2 (Tan et al. 2007). The latter is a functional enzymatic component of the polycomb repressive complex 2 that functions to silence tumorsuppressor genes by catalyzing the addition of three methyl groups to $\mathrm{H} 3 \mathrm{~K} 27$, which is a modification that leads to chromatin condensation and transcriptional repression (Cao et al. 2002, Margueron \& Reinberg 2011). UNC0642 can reduce H3K9me2 level by selectively inhibiting HMTs G9a and GLP (Liu et al. 2013), which can mono- or dimethylate H3K9 (Shinkai \& Tachibana
2011). A previous study has shown that UNC0642 can enhance chromatin accessibility and induce transcriptional activation within the corresponding regions (Kim et al. 2017). Both of them harbor potential for activating embryonic chromatin, thereby promoting the development competence of cloned embryos.

In this study, we examined the effects of DZNep and UNC0642 treatments on the in vitro development of pig SCNT embryos. The results showed that the two compounds could improve the in vitro development of pig SCNT embryos by reducing the levels of H3K27me3 or H3K9me2 at the 2-cell, 4-cell, and blastocyst stages. Incubation of SCNT embryos with varying concentrations of the two compounds revealed that $10 \mathrm{nM}$ DZNep or $5 \mathrm{nM}$ UNC0642 showed the best promoting effect on pig SCNT embryo development, whereas increasing the dosage rendered detrimental effects, as manifested by significantly decreased blastocyst rate. Furthermore, long-term treatment (48 or $72 \mathrm{~h}$ ) or combined use of the compounds showed less or no improvement to the embryos. This detrimental effect might be attributed to the complete dysfunction of the corresponding chromatinmodifying enzymes, EZH2 and G9a, which are targeted by the compounds, because these enzymes are required for early embryonic development. Either EZH2- or G9aknockout mice has shown embryonic lethality at early stages of mouse development ( $\mathrm{O}^{\prime}$ Carroll et al. 2001, Tachibana et al. 2002, 2005). These data indicated that an appropriate but nontoxic dose and exposure duration of the chromatin-modifying compounds should be determined before treatment. TUNEL assays showed that treatment using either compound significantly lowered the apoptosis level in cloned embryos compared with the untreated control, which corroborated with the beneficial effect of the two compounds in terms of improved blastocyst rate.

Our findings are in line with previous studies using embryos of mouse, pig and other species, in which loss or inhibition of aberrant histone methylation

Table 5 Effect of combined treatment of $10 \mathrm{~nm}$ DZNep and $5 \mathrm{~nm}$ UNC0642 for different exposure durations on the developmental competence of pig cloned embryos.

\begin{tabular}{lcccccc}
\hline $\begin{array}{l}\text { Treatment duration } \\
\text { (h) (replicates) }\end{array}$ & Embryos $(n)$ & $\begin{array}{c}\text { Cleaved } \\
\text { embryos }(n)\end{array}$ & Cleavage rate $(\%)$ & Blastocysts $(n)$ & Blastocyst rate $(\%)$ & Total cell number \\
\hline $0(3)$ & 91 & 70 & $77.18 \pm 2.73$ & 10 & $11.04 \pm 1.24$ & $47.00 \pm 1.27$ \\
$24(3)$ & 124 & 94 & $75.80 \pm 1.13$ & 17 & $13.70 \pm 0.52$ & $52.22 \pm 1.62$ \\
$48(3)$ & 106 & 82 & $77.33 \pm 1.81$ & 12 & $11.30 \pm 1.54$ & $49.43 \pm 1.13$ \\
\hline
\end{tabular}


A
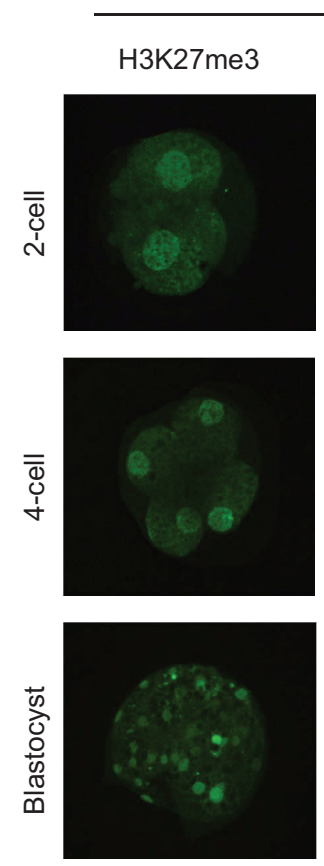

Control

Hoechst 33342

$+\mathrm{H} 3 \mathrm{~K} 27 \mathrm{me} 3$
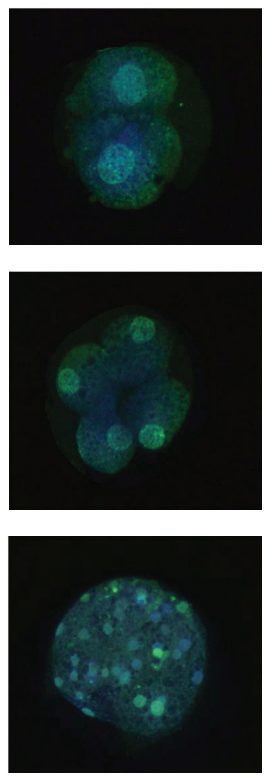

DZNep
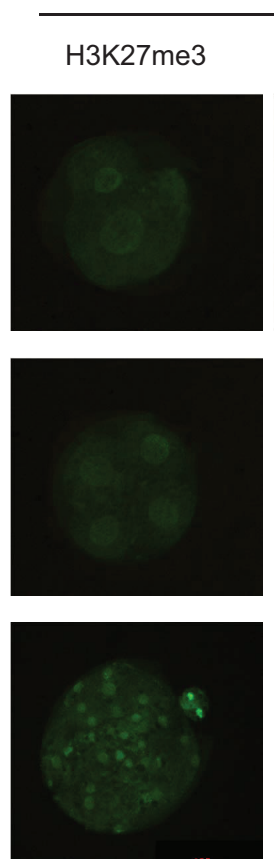

B

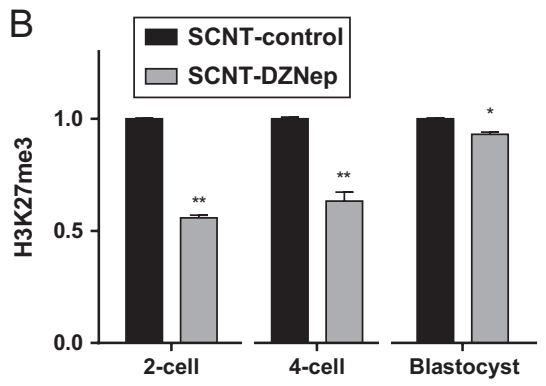

Figure $2 \mathrm{H} 3 \mathrm{~K} 27$ me3 modification is decreased in cloned pig embryos treated with $10 \mathrm{nM}$ DZNep for $24 \mathrm{~h}$. (A) Immunofluorescence analysis of H3K27me3 levels of cloned embryos, at 2-cell, 4-cell and blastocyst stages, treated with $10 \mathrm{nM}$ DZNep and DMSO control. (B) Mean fluorescence intensity quantified for the H3K27me3 level. H3K27me3 signals following DZNep treatment in 2-cell, 4-cell embryos and blastocysts are significantly lower than those in DMSO-treated embryos. $P$ values represent the significance of difference in fluorescence signals between DZNep and DMSO treatment groups. ${ }^{*} P<0.05,{ }^{* *} P<0.01$. Scale bars $=100 \mu \mathrm{m}$.

A
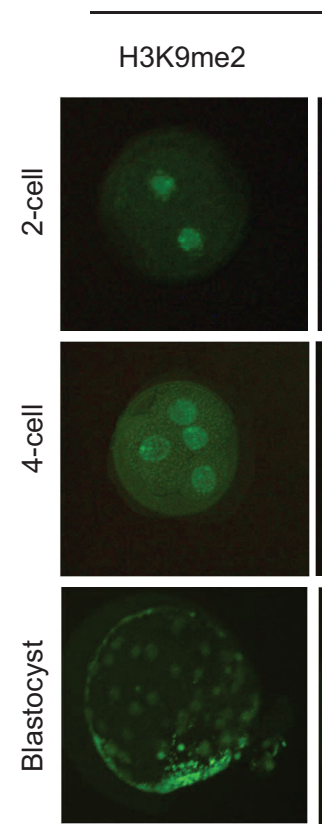

Control
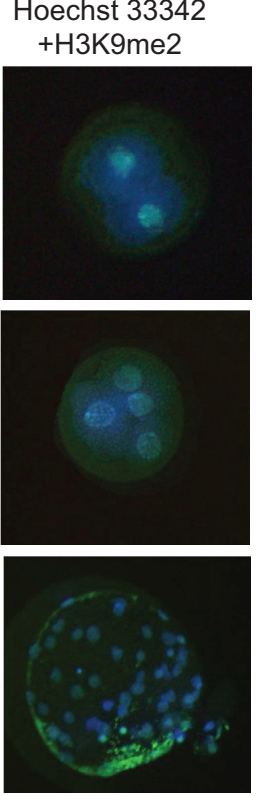

UNC0642
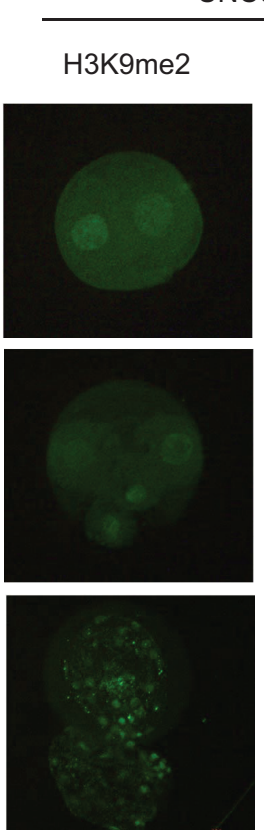

Hoechst 33342

+H3K27me3
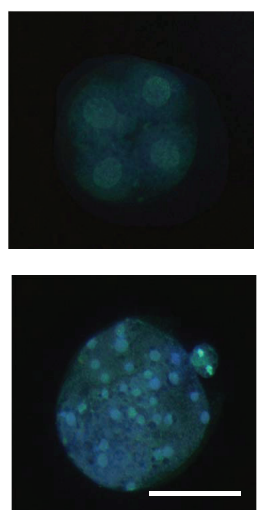
A
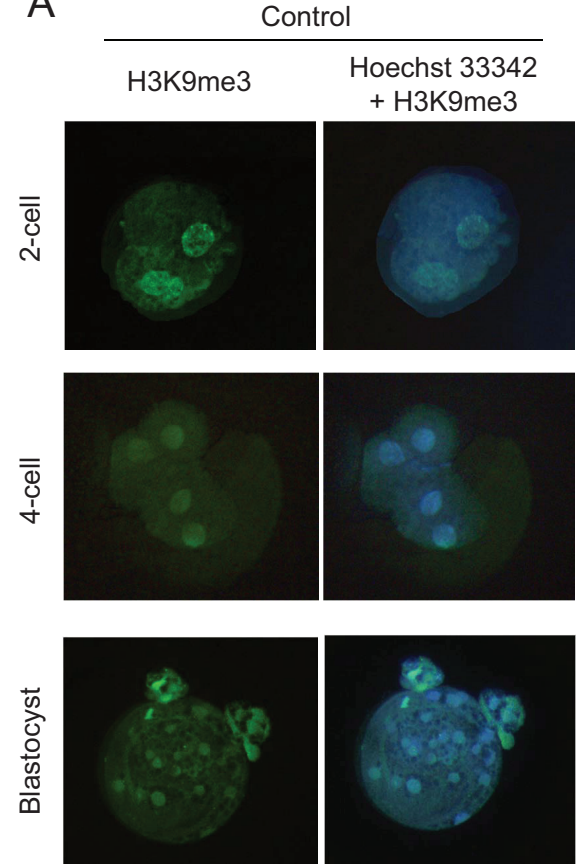

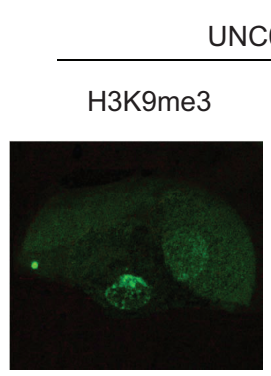

NC0642

Hoechst 33342

$+\mathrm{H} 3 \mathrm{~K} 9 \mathrm{me} 3$
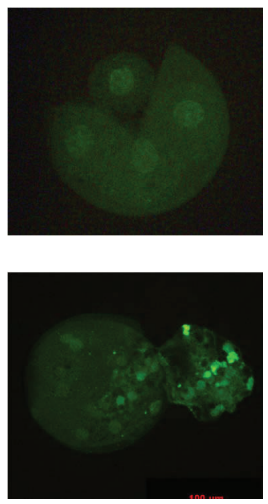

$\mathrm{B}$

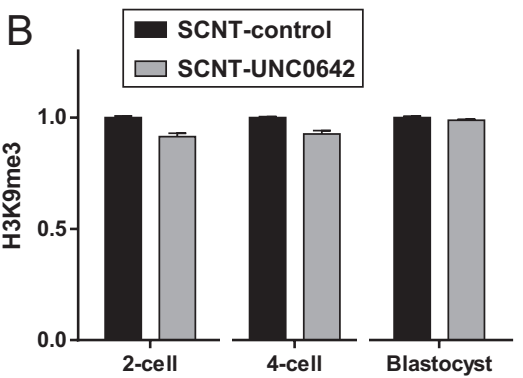

Figure 4 UNC0642 treatment does not affect H3K9me3 levels of cloned pig embryos. (A) Representative immunofluorescence images of H3K9me3 levels of cloned embryos at different developmental stages after UNC0642 treatment. (B) Mean fluorescence intensity quantified for the H3K9me3 levels. No significant difference in fluorescence intensity are observed between UNC0642 and DMSO treatment groups. Scale bars $=100 \mu \mathrm{m}$.

significantly improved cloning efficiency (Matoba et al. 2014, 2018, Huang et al. 2016, Xie et al. 2016, Cao et al. 2017). Treatment with $50 \mathrm{~nm}$ BIX-01294 (G9a inhibitor) for 14-16h after activation could enhance the developmental competence of pig SCNT embryos in vitro (blastocyst rate $16.4 \%$ vs $23.2 \%$ ) and in vivo (cloning rate $1.59 \%$ vs $2.96 \%$ ) (Huang et al. 2016). Removal of the H3K9me3 barrier by mRNA injection of a H3K9me3-specific demethylase, $K d m 4 d$, allowed cloned mouse embryos to develop at a rate similar to that of IVF embryos $(88.6 \%$ blastocyst rate and $7.6 \%$ cloning rate using cumulus cells as donor vs $26.0 \%$ and $0 \%$, respectively) (Matoba et al. 2014). They further improved the mouse cloning efficiency to more than $20 \%$ by using a combination of Xist knockout donor cells and overexpression of $K d m 4 d$. Although such a high
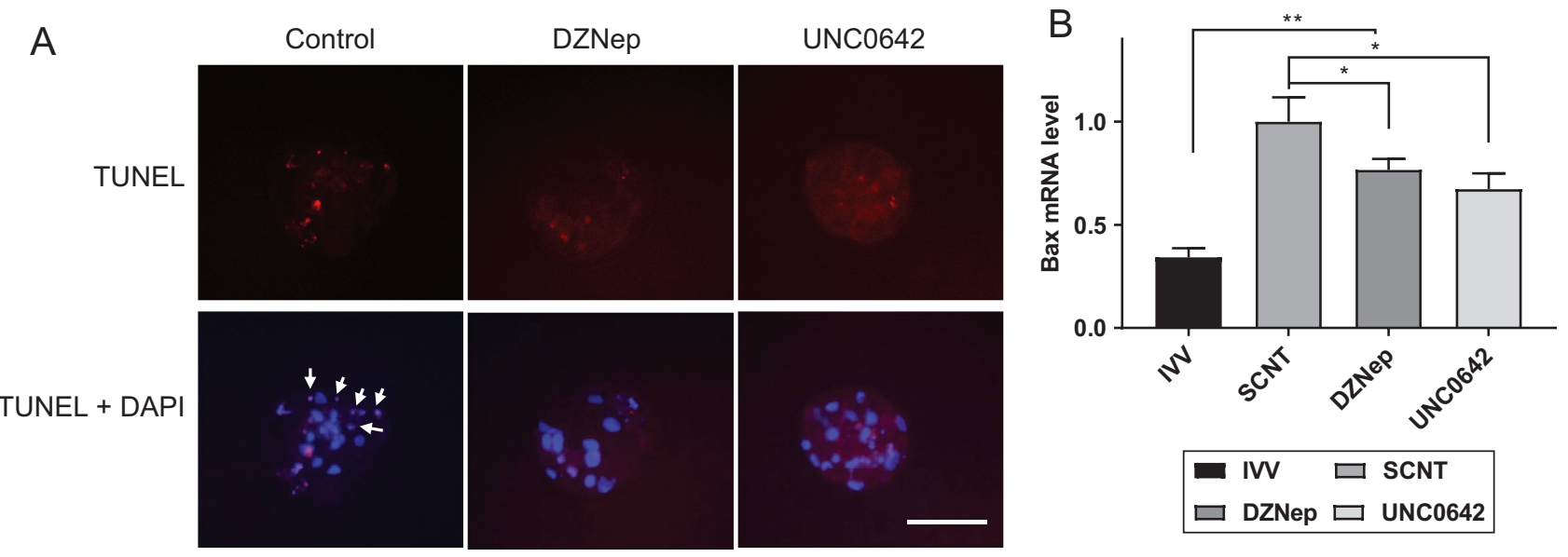

Figure 5 Detection of apoptotic index in cloned blastocysts. (A) TUNEL assay on cloned blastocysts from control, $10 \mathrm{nM}$ DZNep and $5 \mathrm{nM}$ UNC0642 treatment groups. DAPI staining showing significant DNA fragmentations (white arrows) in control group. (B) Significantly decreased Bax mRNA expression in DZNep-, and UNC0642-treated blastocysts compared with control. ${ }^{*} P<0.05, * * P<0.01$. Scale bars $=100 \mu \mathrm{m}$. IVV, in vivo-derived embryos. 


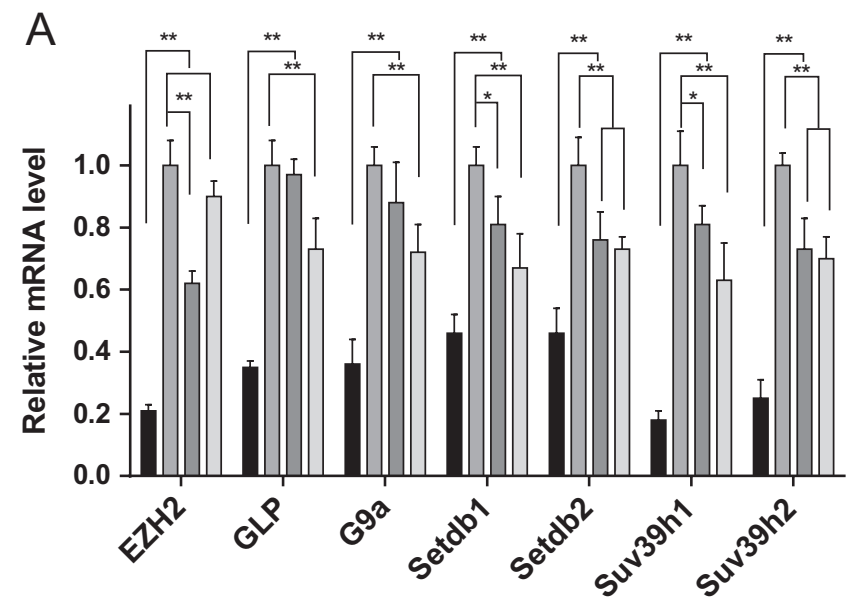

$\square$ IVV $\square$ SCNT $\square$ DZNep $\square$ UNC0642

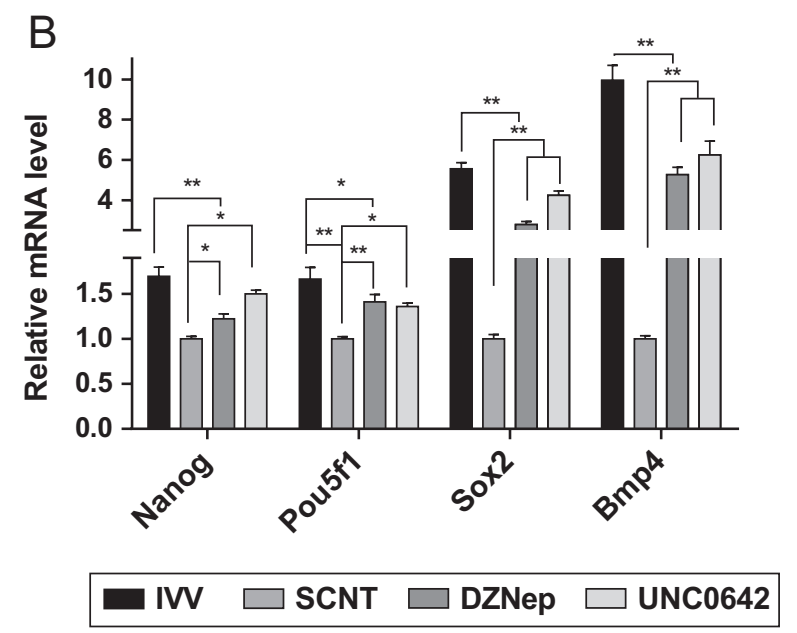

Figure 6 Relative mRNA abundance of HMT genes (EZH2, GLP, G9a, Setdb1, Setdb2, Suv39h1 and Suv39h2) (A) and pluripotency genes (Nanog, Pou5f1, Sox2 and Bmp4) (B) in cloned blastocysts produced

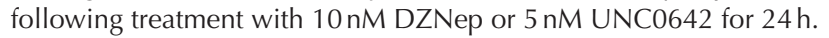
The expression levels were normalized against actin. $* P<0.05$,

${ }^{* *} P<0.01$ between the two groups. IVV, in vivo-derived embryos.

cloning efficiency can be achieved through combining multiple approaches to remove reprogramming barriers, defective postimplantation development and placental overgrowth were still commonly observed (Matoba et al. 2018). This result implies additional barriers exist for high-efficiency animal cloning, and simultaneous modulation of multiple epigenetics marks could facilitate further improvement of cloning efficiency.

Examining the expression levels of the multiple HMTs showed that EZH2 and G9a/GLP expressions in the SCNT blastocysts were significantly inhibited by DZNep and UNC0642 treatments, respectively. However, we also observed inhibitory effects to other HMTs, including Setdb1, Setdb2, Suv39h1 and Suv39h2. This result suggested that DZNep and UNC0642 may be nonspecific HMT inhibitors. A previous report has shown that DZNep targets Setdb1 at the transcription level in human cancer cells, thereby implicating DZNep to inhibit diverse epigenetic targets (Lee \& Kim 2013). Another study has also reported that DZNep globally inhibits histone methylation and is nonselective, and the authors observed the nonselective inhibitory effect of some of the other HMT inhibitors on histone methylation (Miranda et al. 2009). The mechanism for broadspectrum inhibition to HMT of the two compounds remains elusive. Inhibition of EZH2 by DZNep was reportedly achieved through a proteolytic degradation process (Tan et al. 2007). However, our data showed these HMTs were regulated at transcriptional level by DZNep, implying a different mechanism of DZNep in regulating the expression of some HMTs. In addition, there is evidence that UNC0642 could inhibit EZH2, although less selective than G9a and GLP (Liu et al. 2013). The selectivity of the compounds may vary in different cells or embryos.

Given that epigenetic changes can act as regulatory switches of gene transcription, which is associated with the modulation of pluripotency in the embryos, we determined the expression levels of pluripotencyrelated genes Nanog, Pou5f1, Sox2 and Bmp4 in the compound-treated SCNT embryos. All these factors showed a marked increase after treatment with either of the two compounds, indicating an enhancement of pluripotency in the SCNT embryos. Improvement of epigenetic reprogramming might result in the increased gene transcripts of pluripotency factors, and thus contribute to the improved developmental competence of SCNT embryos.

\section{Declaration of interest}

The authors declare that there is no conflict of interest that could be perceived as prejudicing the impartiality of the research reported.

\section{Funding}

This study was supported by the grants from the National Natural Science Foundation of China (31772554 and 31772555) and the Department of Science and Technology of Guangdong Province (2016B020233006 and 2017B020201009).

\section{References}

Allis CD \& Jenuwein T 2016 The molecular hallmarks of epigenetic control. Nature Reviews Genetics 17 487-500. (https://doi.org/10.1038/ nrg.2016.59)

Beaujean N, Taylor J, Gardner J, Wilmut I, Meehan R \& Young L 2004 Effect of limited DNA methylation reprogramming in the normal sheep embryo on somatic cell nuclear transfer. Biology of Reproduction 71 185-193. (doi:10.1095/biolreprod.103.026559)

Campbell KHS, Fisher P, Chen WC, Choi I, Kelly RDW, Lee JH \& Xhu J 2007 Somatic cell nuclear transfer: past, present and future 
perspectives. Theriogenology 68 S214-S231. (https://doi.org/10.1016/j. theriogenology.2007.05.059)

Cao R, Wang L, Wang H, Xia L, Erdjument-Bromage H, Tempst P, Jones RS \& Zhang Y 2002 Role of histone H3 lysine 27 methylation in polycombgroup silencing. Science 298 1039-1043. (https://doi.org/10.1126/ science.1076997)

Cao Z, Li Y, Chen Z, Wang H, Zhang M, Zhou N, Wu R, Ling Y, Fang F, Li N et al. 2015 Genome-wide dynamic profiling of histone methylation during nuclear transfer-mediated porcine somatic cell reprogramming. PLoS One 10 e0144897. (https://doi.org/10.1371/journal.pone.0144897)

Cao Z, Hong R, Ding B, Zuo X, Li H, Ding J, Li Y, Huang W \& Zhang Y 2017 TSA and BIX-01294 induced normal DNA and histone methylation and increased protein expression in porcine somatic cell nuclear transfer embryos. PLoS One 12 e0169092. (https://doi.org/10.1371/journal. pone.0169092)

Chen J, Liu H, Liu J, Qi J, Wei B, Yang J, Liang H, Chen Y, Chen J, Wu Y et al. 2013 H3K9 methylation is a barrier during somatic cell reprogramming into iPSCs. Nature Genetics 45 34-42. (https://doi.org/10.1038/ng.2491)

Chung YG, Eum JH, Lee JE, Shim SH, Sepilian V, Hong SW, Lee Y, Treff NR, Choi YH, Kimbrel EA et al. 2014 Human somatic cell nuclear transfer using adult cells. Cell Stem Cell 14 777-780. (https://doi.org/10.1016/j. stem.2014.03.015)

Chung YG, Matoba S, Liu Y, Eum JH, Lu F, Jiang W, Lee JE, Sepilian V, Cha KY, Lee DR et al. 2015 Histone demethylase expression enhances human somatic cell nuclear transfer efficiency and promotes derivation of pluripotent stem cells. Cell Stem Cell 17 758-766. (https://doi. org/10.1016/j.stem.2015.10.001)

Dean W, Santos F, Stojkovic M, Zakhartchenko V, Walter J, Wolf E \& Reik W 2001 Conservation of methylation reprogramming in mammalian development: aberrant reprogramming in cloned embryos. PNAS 98 13734-13738. (https://doi.org/10.1073/pnas.241522698)

Enright BP, Kubota C, Yang X \& Tian XC 2003 Epigenetic characteristics and development of embryos cloned from donor cells treated by trichostatin A or 5-aza-2'-deoxycytidine. Biology of Reproduction 69 896-901. (https://doi.org/10.1095/biolreprod.103.017954)

Galli C, Lagutina I, Perota A, Colleoni S, Duchi R, Lucchini F \& Lazzari G 2012 Somatic cell nuclear transfer and transgenesis in large animals: current and future insights. Reproduction in Domestic Animals 47 (Supplement 3) 2-11. (https://doi.org/10.1111/j.14390531.2012.02045.x)

Gannon OM, Merida de Long L, Endo-Munoz L, Hazar-Rethinam M \& Saunders NA 2013 Dysregulation of the repressive H3K27 trimethylation mark in head and neck squamous cell carcinoma contributes to dysregulated squamous differentiation. Clinical Cancer Research 19 428-441. (https://doi.org/10.1158/1078-0432.CCR-12-2505)

Glanzner WG, Rissi VB, de Macedo MP, Mujica LKS, Gutierrez K, Bridi A, de Souza JRM, Gonçalves PBD \& Bordignon V 2018 Histone 3 lysine 4,9 , and 27 demethylases expression profile in fertilized and cloned bovine and porcine embryos. Biology of Reproduction 98 742-751. (https://doi.org/10.1093/biolre/ioy054)

Greer EL \& Shi Y 2012 Histone methylation: a dynamic mark in health, disease and inheritance. Nature Reviews Genetics 13 343-357. (https:// doi.org/10.1038/nrg3173)

Hochedlinger K \& Jaenisch R 2002 Monoclonal mice generated by nuclear transfer from mature B and T donor cells. Nature 415 1035-1038. (https://doi.org/10.1038/nature718)

Huang J, Zhang H, Yao J, Qin G, Wang F, Wang X, Luo A, Zheng Q, Cao C \& Zhao J 2016 BIX-01294 increases pig cloning efficiency by improving epigenetic reprogramming of somatic cell nuclei. Reproduction 151 39-49. (https://doi.org/10.1530/REP-15-0460)

Hyun K, Jeon J, Park K \& Kim J 2017 Writing, erasing and reading histone lysine methylations. Experimental and Molecular Medicine 49 e324. (https://doi.org/10.1038/emm.2017.11)

Kang YK, Koo DB, Park JS, Choi YH, Chung AS, Lee KK \& Han YM 2001 Aberrant methylation of donor genome in cloned bovine embryos. Nature Genetics 28 173-177. (https://doi.org/10.1038/88903)

Kim Y, Lee HM, Xiong Y, Sciaky N, Hulbert SW, Cao X, Everitt JI, Jin J, Roth BL \& Jiang YH 2017 Targeting the histone methyltransferase G9a activates imprinted genes and improves survival of a mouse model of Prader-Willi syndrome. Nature Medicine 23 213-222. (https://doi. org/10.1038/nm.4257)
Lai L \& Prather RS 2003 Production of cloned pigs by using somatic cells as donors. Cloning and Stem Cells 5 233-241. (https://doi. org/10.1089/153623003772032754)

Lee JK \& Kim KC 2013 DZNep, inhibitor of S-adenosylhomocysteine hydrolase, down-regulates expression of SETDB1 H3K9me3 HMTase in human lung cancer cells. Biochemical and Biophysical Research Communications 438 647-652. (https://doi.org/10.1016/j. bbrc.2013.07.128)

Li J, Svarcova O, Villemoes K, Kragh PM, Schmidt M, Bøgh IB, Zhang Y, Du Y, Lin L, Purup S et al. 2008 High in vitro development after somatic cell nuclear transfer and trichostatin $\mathrm{A}$ treatment of reconstructed porcine embryos. Theriogenology 70 800-808. (https://doi.org/10.1016/j. theriogenology.2008.05.046)

Liu F, Barsyte-Lovejoy D, Li F, Xiong Y, Korboukh V, Huang XP, AllaliHassani A, Janzen WP, Roth BL, Frye SV et al. 2013 Discovery of an in vivo chemical probe of the lysine methyltransferases G9a and GLP. Journal of Medicinal Chemistry 56 8931-8942. (https://doi.org/10.1021/ jm401480r)

Liu Z, Cai Y, Wang Y, Nie Y, Zhang C, Xu Y, Zhang X, Lu Y, Wang Z, Poo M et al. 2018 Cloning of macaque monkeys by somatic cell nuclear transfer. Cell 172 881.e7-887.e7. (https://doi.org/10.1016/j.cell.2018.01.020)

Long CR, Westhusin ME \& Golding MC 2014 Reshaping the transcriptional frontier: epigenetics and somatic cell nuclear transfer. Molecular Reproduction and Development 81 183-193. (https://doi.org/10.1002/ mrd.22271)

Margueron R \& Reinberg D 2011 The Polycomb complex PRC2 and its mark in life. Nature 469 343-349. (https://doi.org/10.1038/nature09784)

Matoba S \& Zhang Y 2018 Somatic cell nuclear transfer reprogramming: mechanisms and applications. Cell Stem Cell 23 471-485. (https://doi. org/10.1016/j.stem.2018.06.018)

Matoba S, Liu Y, Lu F, Iwabuchi KA, Shen L, Inoue A \& Zhang Y 2014 Embryonic development following somatic cell nuclear transfer impeded by persisting histone methylation. Cell 159 884-895. (https:// doi.org/10.1016/j.cell.2014.09.055)

Matoba S, Wang H, Jiang L, Lu F, Iwabuchi KA, Wu X, Inoue K, Yang L, Press W, Lee JT et al. 2018 Loss of H3K27me3 imprinting in somatic cell nuclear transfer embryos disrupts post-implantation development. Cell Stem Cell 23 343.e5-354.e5. (https://doi.org/10.1016/j. stem.2018.06.008).

Miranda TB, Cortez CC, Yoo CB, Liang G, Abe M, Kelly TK, Marquez VE \& Jones PA 2009 DZNep is a global histone methylation inhibitor that reactivates developmental genes not silenced by DNA methylation. Molecular Cancer Therapeutics 8 1579-1588. (https://doi. org/10.1158/1535-7163.MCT-09-0013)

Mozzetta C, Pontis J, Fritsch L, Robin P, Portoso M, Proux C, Margueron R \& Ait-Si-Ali S 2014 The histone H3 lysine 9 methyltransferases G9a and GLP regulate polycomb repressive complex 2-mediated gene silencing. Molecular Cell 53 277-289. (https://doi.org/10.1016/j. molcel.2013.12.005)

Niemann H \& Wrenzycki C 2000 Alterations of expression of developmentally important genes in preimplantation bovine embryos by in vitro culture conditions: implications for subsequent development. Theriogenology $53 \quad 21-34 . \quad$ (https://doi.org/10.1016/S0093691X(99)00237-X)

Nottke A, Colaiácovo MP \& Shi Y 2009 Developmental roles of the histone lysine demethylases. Development 136 879-889. (https://doi. org/10.1242/dev.020966)

O'Carroll D, Erhardt S, Pagani M, Barton SC, Surani MA \& Jenuwein T 2001 The polycomb-group gene Ezh2 is required for early mouse development. Molecular and Cellular Biology 21 4330-4336. (https:// doi.org/10.1128/MCB.21.13.4330-4336.2001)

Onder TT, Kara N, Cherry A, Sinha AU, Zhu N, Bernt KM, Cahan P, Marcarci BO, Unternaehrer J, Gupta PB et al. 2012 Chromatinmodifying enzymes as modulators of reprogramming. Nature 483 598-602. (https://doi.org/10.1038/nature10953)

Onishi A, Iwamoto M, Akita T, Mikawa S, Takeda K, Awata T, Hanada H \& Perry AC 2000 Pig cloning by microinjection of fetal fibroblast nuclei. Science 289 1188-1190. (https://doi.org/10.1126/ science.289.5482.1188)

Ostrup O, Reiner AH, Aleström P \& Collas P 2014 The specific alteration of histone methylation profiles by DZNep during early zebrafish 
development. Biochimica et Biophysica Acta 1839 1307-1315. (https:// doi.org/10.1016/j.bbagrm.2014.09.013)

Pan MR, Hsu MC, Chen LT \& Hung WC 2018 Orchestration of H3K27 methylation: mechanisms and therapeutic implication. Cellular and Molecular Life Sciences 75 209-223.(https://doi.org/10.1007/s00018017-2596-8)

Polejaeva IA, Chen SH, Vaught TD, Page RL, Mullins J, Ball S, Dai Y, Boone J, Walker S, Ayares DL et al. 2000 Cloned pigs produced by nuclear transfer from adult somatic cells. Nature 407 86-90. (https://doi. org/10.1038/35024082)

Prather RS, Hawley RJ, Carter DB, Lai L \& Greenstein JL 2003 Transgenic swine for biomedicine and agriculture. Theriogenology 59 115-123. (https://doi.org/10.1016/S0093-691X(02)01263-3)

Rideout WM 3rd, Eggan K \& Jaenisch R 2001 Nuclear cloning and epigenetic reprogramming of the genome. Science 293 1093-1098. (https://doi.org/10.1126/science.1063206)

Santos F, Zakhartchenko V, Stojkovic M, Peters A, Jenuwein T, Wolf E, Reik W \& Dean W 2003 Epigenetic marking correlates with developmental potential in cloned bovine preimplantation embryos. Current Biology 13 1116-1121. (https://doi.org/10.1016/S09609822(03)00419-6)

Shinkai Y \& Tachibana M 2011 H3K9 methyltransferase G9a and the related molecule GLP. Genes and Development 25 781-788. (https:// doi.org/10.1101/gad.2027411)

Tachibana M, Sugimoto K, Nozaki M, Ueda J, Ohta T, Ohki M, Fukuda M, Takeda N, Niida H, Kato H 2002 G9a histone methyltransferase plays a dominant role in euchromatic histone $\mathrm{H} 3$ lysine 9 methylation and is essential for early embryogenesis. Genes and Development $\mathbf{1 6}$ 1779-1791. (https://doi.org/10.1101/gad.989402)

Tachibana M, Ueda J, Fukuda M, Takeda N, Ohta T, Iwanari H, Sakihama T, Kodama T, Hamakubo T \& Shinkai Y 2005 Histone methyltransferases G9a and GLP form heteromeric complexes and are both crucial for methylation of euchromatin at H3-K9. Genes and Development 19 815-826. (https://doi.org/10.1101/gad.1284005)

Tachibana M, Amato P, Sparman M, Gutierrez NM, Tippner-Hedges R, Ma H, Kang E, Fulati A, Lee HS, Sritanaudomchai H et al. 2013 Human embryonic stem cells derived by somatic cell nuclear transfer. Cell 153 1228-1238. (https://doi.org/10.1016/j.cell.2013.05.006)

Tan J, Yang X, Zhuang L, Jiang X, Chen W, Lee PL, Karuturi RKM, Tan PBO, Liu ET \& Yu Q 2007 Pharmacologic disruption of Polycomb-repressive complex 2-mediated gene repression selectively induces apoptosis in cancer cells. Genes and Development 21 1050-1063. (https://doi. org/10.1101/gad.1524107)

Thuan NV, Kishigami S \& Wakayama T 2010 How to improve the success rate of mouse cloning technology. Journal of Reproduction and Development 56 20-30. (https://doi.org/10.1262/jrd.09-221A)

Torres-Padilla ME, Parfitt DE, Kouzarides T \& Zernicka-Goetz M 2007 Histone arginine methylation regulates pluripotency in the early mouse embryo. Nature 445 214-218. (https://doi.org/10.1038/nature05458)

Wakayama T, Perry ACF, Zuccotti M, Johnson KR \& Yanagimachi R 1998 Full-term development of mice from enucleated oocytes injected with cumulus cell nuclei. Nature 394 369-374. (https://doi. org/10.1038/28615)

Wilmut I, Schnieke AE, McWhir J, Kind AJ \& Campbell KHS 1997 Viable offspring derived from fetal and adult mammalian cells. Nature 385 810-813. (https://doi.org/10.1038/385810a0)

Wilmut I, Beaujean N, de Sousa PA, Dinnyes A, King TJ, Paterson LA, Wells DN \& Young LE 2002 Somatic cell nuclear transfer. Nature $\mathbf{4 1 9}$ 583-587. (https://doi.org/10.1038/nature01079)

Xie B, Zhang H, Wei R, Li Q, Weng X, Kong Q \& Liu Z 2016 Histone H3 lysine 27 trimethylation acts as an epigenetic barrier in porcine nuclear reprogramming. Reproduction 151 9-16. (https://doi.org/10.1530/REP15-0338)

Zhang S, Chen X, Wang F, An X, Tang B, Zhang X, Sun L \& Li Z 2016 Aberrant DNA methylation reprogramming in bovine SCNT preimplantation embryos. Scientific Reports 6 30345. (https://doi.org/10.1038/srep30345)

Zhao J, Ross JW, Hao Y, Spate LD, Walters EM, Samuel MS, Rieke A, Murphy CN \& Prather RS 2009 Significant improvement in cloning efficiency of an inbred miniature pig by histone deacetylase inhibitor treatment after somatic cell nuclear transfer. Biology of Reproduction $\mathbf{8 1}$ 525-530. (https://doi.org/10.1095/biolreprod.109.077016)

Received 4 November 2018

First decision 26 November 2018

Revised manuscript received 11 December 2018

Accepted 7 February 2019 